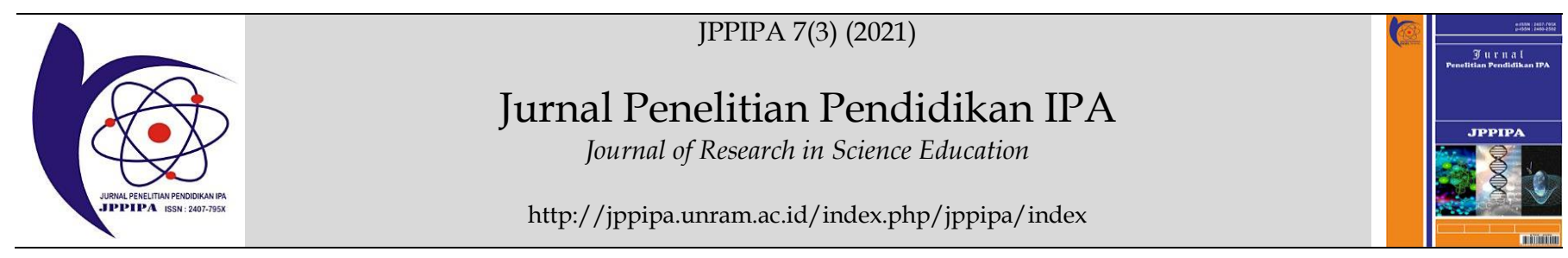

\title{
Curriculum and Student Analysis of Interactive Electronic Book Based on Project in Strategy and Design of Learning Subject
}

\author{
Diana Susanti1 ${ }^{1}$, Vivi Fitriani ${ }^{*}$, Liza Yulia Sari ${ }^{1}$ \\ ${ }^{1}$ Department of Biology Education, STKIP PGRI West Sumatra, Indonesia \\ DOI: 10.29303/jppipa.v7i3.684
}

\section{Article Info}

Received: April 15th, 2021

Revised: May 27th, 2021

Accepted: May 31th, 2021

\begin{abstract}
Biology learning strategies and designs are courses that teach the principles of learning and teaching and apply them in the biology learning process. So far, students only use printed textbooks as a reference. This is not in accordance with the existing needs, because students are more likely to look for teaching materials from the Internet. This results in learning to be monotonous, not interactive and does not increase student creativity. It is for this reason that researchers develop project-based interactive books so that learning becomes interactive and can increase student creativity. The purpose of this research is to determine the curriculum analysis and student analysis in the development of project-based interactive books. This research is a development research using the $4 \mathrm{D}$ model at a specified stage. The analysis data were obtained through descriptive analysis. The resulted showed that 10 materials need to be developed in the module. Can prove that there are ten materials developed. It can be concluded that there are ten materials developed in project-based interactive digital books and the age range of students is $18-21$ years.
\end{abstract}

Keywords: Curriculum analysis; student analysis; Interactive; Electronic Book

Citation: Susanti, D., Fitriani, V., \& Sari, L. (2021). Curriculum and Student Analysis of Interactive Electronic Book Based on Project in Strategy and Design of Learning Subject. Jurnal Penelitian Pendidikan IPA, 7(3), 344-349. doi:https:// doi.org/10.29303/jppipa.v7i3.684

\section{Introduction}

Strategic courses Strategy and biology learning design is one of the courses taught in the Biology Education Study Program of STKIP PGRI West Sumatra. This course discusses 1) learning strategies, approaches, learning methods; 2) learning models, assessments, tools that can be used in the learning process; 3) basic principles of learning, teacher competence, teacher duties and responsibilities, teacher code of ethics and material facts, concepts, principles, procedures, law, and theory; 4) annual program, semester program, and learning implementation plan components, learning methods and approaches; 5) learning models, the steps of the learning model and the advantages and disadvantages of the learning model; 6) basic teaching skills; 7) teaching materials. 8) the syllabus component, the steps for the preparation of the syllabus, the lesson plan component, and the steps for the preparation; 9) remedial and enrichment program; 10) approaches, learning methods, learning models, assessments, tools that can be used in teaching certain materials in the learning process and classroom management components. So in this course students are required to be able to master the material. 
From interviews with several students, it is known that students who take biology learning strategy and design courses are in the age range 18-21 years. This is reinforced by data obtained from the admin of the Biology Department STKIP PGRI SUMBAR.

But what is found in the field is that students do not understand the material because they only rely on the material provided by the lecturer, namely in the form of power points. When given the assignment, most of the students looked for material from the internet in the form of blogs, and the truth of the blog could not be accounted for.

The biology learning strategy and design course is an educational subject with complex material content, but it must be discussed in 1 semester with a weight of 3 credits. Due to the limited time and complexity of the biology learning strategy and design course content that must be taught to students, it is very appropriate and suitable if teaching materials are made in digital form, so that the teaching materials created become simpler, interactive, interesting, and easy to understand by students (Firdawati, 2021), and of course, it can expedite the learning process. Teaching materials can be designed using interactive multimedia that can increase student motivation (Qosyim, 2017).

Based on the problems found, it is necessary to find appropriate solutions/breakthroughs to overcome them. The breakthrough used is trying to develop project-based digital books.

Digital books are suitable to be developed at STKIP PGRI SUMBAR because most students already have computers/laptops and cellphones. Based on this, digital books exist to overcome limitations in the faceto-face-based traditional teaching and learning process which is limited by space and time, so that the relationship between students and lecturers can teaching materials that can be made for independent learning with complete content are modules (Addiin, 2014). The development of the 21st century, known as technological development, requires that everything take advantage of technology so that modules can be developed into e-modules (Divayana et al, 2020). The advantages of e-modules include increasing learning motivation and learning outcomes (Fadillah, 2014).

Interactive electronic books are the best alternative that can contribute to improving reading comprehension and reading interest. Electronic books can be combined with innovative learning models that are seen as being able to improve learning outcomes. The learning model used in this research is projectbased learning. Project-based learning is an approach to creating a learning environment that can encourage students to construct personal knowledge and skills. In recent years, many studies have revealed that project- based learning is very effective if it is actually applied in learning, including: (a) increasing student motivation in learning (Liu, 2016); (b) facilitate a better concept understanding process (Wekesa et al, 2016); (c) increasing involvement in student learning and academic performance (Iwamoto, et al, 2016); (d) increasing the ability to solve problems in various situations (Movahedzadeh, et al, 2012), and (e) improving students' social skills (Styla et al, 2016) This study aims to determine student curriculum analysis and analysis to develop biology learning media modules. based on Project Based Learning.

\section{Method}

Based on the problems studied, the type of research used is development research. According to Komalasari et al (2019), this research is a method for producing certain products and testing the effectiveness of these products. The research model used in this study is the four-D model. The development of the Four-D model consists of 4 main stages: define (determine material), design (develop), develop (develop), and disseminate (deployment) (Trianto, 2013). The development of the procedure in this study is only at the define stage, which aims to find out the basic problems needed in developing projectbased interactive digital books.

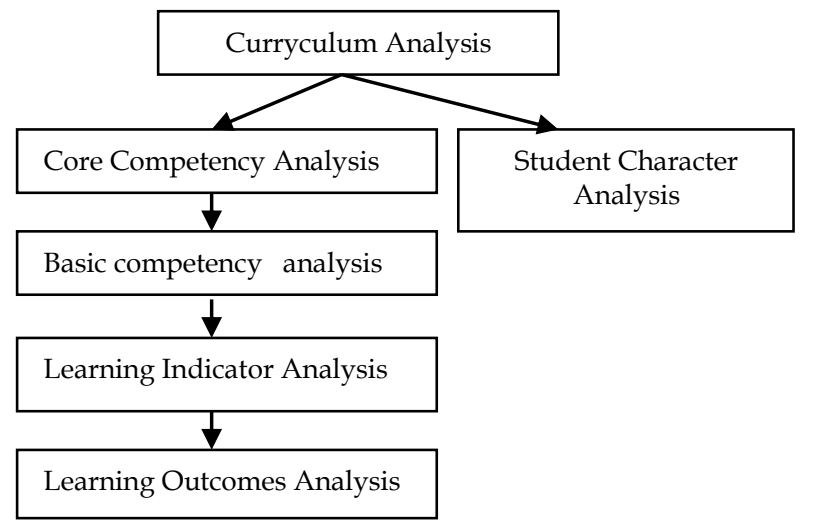

Figure 1. Research Schema

One way to do this is by analyzing the curriculum and analyzing students. The data was obtained in the form of descriptive data that describes the results of curriculum analysis and student analysis in biology learning in biology learning strategy and design courses on project-based interactive e-books. The results of this analysis can be seen from several components in the curriculum for biology learning strategies and designs as stated in the Semester Learning Plan. Then the data were analyzed descriptively. 


\section{Result and Discussion}

The results of the analysis of curriculum media biology learning can be seen from the learning outcomes of the study program graduates and biology learning strategy and design courses. The results found that in this course there were several learning outcomes in this subject, such as attitudes and values, general skills, special skills and knowledge.

For student attitude skills are expected to be honest, polite, respect the opinions of others, able to cooperate, be disciplined and responsible. Learning outcomes for students' general skills are expected to be able to apply logical, critical, systematic, innovative, quality and measurable thinking in doing specific jobs in their field of expertise and in accordance with work competency standards in the relevant field. Able to show independent, quality, and measurable performance. Able to be responsible for the achievement of group work and to evaluate the completion of work assigned to workers under their responsibility. Able to carry out the self-evaluation process of the work group under their responsibility, and able to manage learning independently. Be smart in sorting and selecting media and evaluation tools according to the curriculum that he teaches by practicing the value of conservation and fostering the character of his students.

As for special skills, it is expected that students who are able to: 1) apply mastery of biological concepts in designing biology by utilizing science and technology and in accordance with National Education Standards, problems in class and school, student development and environmental character so as to produce learning designs that encourage participation active and develop the potential of each student, 2) Able to apply mastery of the concepts of biology and education in implementing biology learning in Indonesian and / or one of the international educational languages by utilizing the development of science and technology in accordance with National Education Standards, problems in class and schools, students and the character of their environment so that students are able to achieve educational goals and actualize the various potentials they have according to the field of work they are engaged in, 3) Able to carry out various innovations in implementing learners Biology with various approaches, strategies, methods, media and learning techniques based on National Education Standards by utilizing science and technology so that students are able to achieve educational goals and implement them according to the field of work they are engaged in in life. 4) Able to analyze the high school biology curriculum through curriculum review activities so as to produce indicators, assessments, strategies and learning media in accordance with the appropriate curriculum. 5) Able to make decisions on student learning outcomes in biology learning, follow-up and reporting, based on assessment data analysis. 6) Able to be responsible for their duties as an educator and to show a high work ethic and responsibility, a sense of pride and confidence as an educator, and able to communicate effectively, based on the teacher's code of ethics, both in the classroom, school and in the community.

From the learning achievements, the points of learning material are arranged systematically so that learning is more focused and organized. There are 10 materials taught in the strategy and learning design course. According to Mahnun (139: 2012), learning materials or materials are curriculum content that is very closely related to course outcomes. Learning materials do not merely mean all descriptions listed in source books or other printed sources, but have a certain classification. Based on this classification, the teacher then chooses which teaching materials will be presented in the planning to achieve the learning outcomes that have been previously formulated as a frame of reference.

Table 1. The Result of Analysis from Main and SubMain Material in Strategy and Biology Learning Subject

\begin{tabular}{|c|c|c|}
\hline No & Main matterial & Subject matter \\
\hline 1 & $\begin{array}{l}\text { Learning strategies, } \\
\text { approaches, learning } \\
\text { methods, learning } \\
\text { models, assessments, } \\
\text { tools that can be used } \\
\text { in the learning } \\
\text { process }\end{array}$ & $\begin{array}{l}\text { 1.1 Learning design } \\
\text { 1.2. Learning strategies } \\
\text { 1.3 Learning methods } \\
\text { 1.4 Learning model } \\
\text { 1.5 Learning approach }\end{array}$ \\
\hline 2 & $\begin{array}{l}\text { Basic principles of } \\
\text { learning, teacher } \\
\text { competence, teacher } \\
\text { duties and } \\
\text { responsibilities, } \\
\text { teacher code of ethics } \\
\text { and material facts, } \\
\text { concepts, principles, } \\
\text { procedures, laws, and } \\
\text { theories }\end{array}$ & $\begin{array}{l}\text { 2.1 Basic principles of } \\
\text { learning } \\
\text { 2.2. Teacher } \\
\text { professionalism and } \\
\text { competence } \\
\text { 2.3. Duties and } \\
\text { responsibilities of the } \\
\text { teacher } \\
\text { 2.4. Meaning, requirements } \\
\text { and code of ethics of } \\
\text { teachers. } \\
\text { 2.5 Facts, concepts, } \\
\text { principles, legal } \\
\text { procedures and theories } \\
\text { 2.6. Biology learning } \\
\text { experience }\end{array}$ \\
\hline 3 & $\begin{array}{l}\text { Annual program, } \\
\text { semester program, } \\
\text { and educational } \\
\text { calendar }\end{array}$ & $\begin{array}{l}\text { 3.1. annual program } \\
\text { 3.2 semester program } \\
\text { 3.3. educational calendar }\end{array}$ \\
\hline 4 & $\begin{array}{l}\text { Analyze approaches, } \\
\text { methods, models, } \\
\text { teaching skills, }\end{array}$ & $\begin{array}{l}\text { 4.1. Learning approaches } \\
\text { 4.2 Learning Methods } \\
\text { 4.3 Learning Model }\end{array}$ \\
\hline
\end{tabular}




\begin{tabular}{|c|c|c|}
\hline & teaching materials, & 4.4 Teaching skills \\
\hline & lesson plans, remedial & 4.5. Teaching materials \\
\hline & and enrichment & 4.6. RPP \\
\hline & & $\begin{array}{l}4.7 \text { Remedials and } \\
\text { enrichment }\end{array}$ \\
\hline 5. & $\begin{array}{l}\text { Simulation of learning } \\
\text { models }\end{array}$ & $\begin{array}{l}\text { 5.1. Cooperative learning } \\
\text { model simulation }\end{array}$ \\
\hline & & $\begin{array}{l}\text { 5.2. Simulation of the K } 13 \\
\text { learning model }\end{array}$ \\
\hline
\end{tabular}

Learning materials are generally classified into three areas, namely knowledge, skills and attitudes. This is in accordance with the objectives to be achieved. The main points of learning materials that have been arranged systematically and focused and the age of the students are taken into consideration in designing electronic printed books. The electronic module or emodule is defined as a learning media using a computer that displays text, images, graphics, audio, animation, and video in the learning process (Nugraha et al, 2015). Smeets et al (2014), revealed that electronic books that are inserted with multimedia features can enrich the experience of reading books if used properly e books can also improve student learning outcomes Siregar et al, 2020).Interactive electronic books are the best alternative that can contribute to improving reading comprehension and reading interest. Electronic books can be combined with innovative learning models that are seen as being able to improve learning outcomes (Diarta et al, 2021).

The learning model used in this research is project-based learning. One learning model that can increase the active role of students in constructing their knowledge is a project-based learning model. Products made by learners during the project provide results that can be authentically measured by educators, in Project Based learning, educators are not more active and train directly, will but educators become companions, facilitators, and understand the thoughts of learners (Iwamoto, 2016). The interactive electronic book-based project-based learning model is able to present meaningful learning (Syukri et al, 2021). The meaning of learning will be able to improve the learning process effectively, resulting in an output of graduates who are skilled, qualified and competent in accordance with the demands of the curriculum (Irawati, 2018).

Teaching materials developed using a project based learning model can increase student activity.Project-based interactive electronic books as one of the teaching materials that emphasize activities that are carried out more by students, this aims to produce more meaningful learning in students (Susanti et al, 2019).
The project-based learning model places the teacher as a facilitator in managing classroom learning with the aim of producing real products that have been designed beforehand (Nugroho and Sukardi, 2018). In the process, students complete a given project carrying out a very complex process starting from how students inventory problems, work collaboratively, develop innovative ideas so that they are able to produce projects that are charged to them . Project-based learning consists of four things, namely: content, conditions, activities, and results (I Wijaya, 2017).

The objectives of implementing project-based learning can be achieved maximally by following five main steps, namely: 1) establishing a theme, 2) establishing a learning context, 3) planning activities, 4) processing activities, and 5) implementing activities for complete the project (Movahedzadeh et al, 2012). This course, equips students with skills in choosing and designing learning strategies. The analysis of the students really determines the teaching materials to be developed (Susanti et al, 2020).

In addition, this course aims to equip students to communicate ideas or concepts they find themselves or modify existing ideas or concepts through digital media. Therefore, the development of this e-module in the form of a project is considered important to increase motivation, conceptual understanding, problemsolving abilities, and social skills (Chiang et al, 2016)

The results of the analysis obtained will be used to design digital books. The format of the digital book is as follows: 1) Introduction which includes the word introduction, table of contents, learning background, learning objectives, brief description, and instructions for using the media. 2) Material. 3) The closing consists of conclusions, suggestions, bibliography, and biodata maker. 4) Evaluation in the form of a test of students' creative thinking skills (Rahmatsyah and Dwiningsih, 2021)

\section{Conclusion}

From the results of this research, it can be concluded that several learning achievements must be achieved, namely attainment learning attainment, general skills learning achievement, special skills learning achievement and knowledge learning achievement, and some material and suitable in age of the students that range in 18-21 years that will be included in the book electronic interactive based on Project in Strategy and Design of Learning Subject. 


\section{Acknowledgments}

Thank you to DRPM DIKTI and STKIP PGRI West Sumatra for funding and facilitating this research.

\section{References}

Addiin, I., Redjeki, T. dan Ariani, S.R.D. (2014). Penerapan Model Pembelajaran Project Based Learning (PjBL) Pada Materi Pokok Larutan Asam dan Basa di Kelas XI IPA 1 SMA N 2 karanganyar tahun ajaran 2013/2014. Jurnal Pendidikan Kimia, 3(4), 7-16. Retrieved from: https://jurnal.fkip.uns.ac.id/index.php/kimia/ article/view / 4442 [Indonesian]

Chiang, C. L. \& Lee H. (2016). The effect of projectbased learning on learning motivation and problem-solving ability of vocational high school students. International Journal of Information and Education Technology, 6(9), 709-712. Retrieved from: http://www.ijiet.org/show-76-881-1.html

Diarta, F., Tiara, Kantun, S., \& Sari, D. E. (2021). The effectiveness of the digital books' usage to improve the XII IPS 3 class students' motivation at SMAN Pakusari Jember. IOP Conference Series: Earth and Environmental Science, 747(1), 12101. https://doi.org/10.1088/17551315/747/1/012101

Divayana, D. G. H., Suyasa, P. W. A., Ariawan, I. P. W., Mahendra, I. W. E., \& Sugiharni, G. A. D. (2019). The Design of Digital Book Content for Assessment and Evaluation Courses by Adopting Superitem Concept Based on Kvisoft Flipbook Maker in era of Industry 4.0. Journal of Physics: Conference Series, 1165, 12020. https:// doi.org/10.1088/17426596/1165/1/012020

Fadillah, A.I., Munoto, L.N., \& Nurlaela, L. (2014). Pengaruh Media Pembelajaran (E- Learning Moodle, LKS) dan Motivasi terhadap Hasil Belajar Pengoperasian Perangkat Lunak Lembar Sebar di SMKN 1 Mojokerto. Pendidikan Vokasi: Teori Dan Praktik, 2 (01). Retrieved from: https://jurnalmahasiswa.unesa.ac.id/index.php $\angle$ pendidikan-vokasi-teori-danprak/article/view/8696 [Indonesian]

Firdawati, R., Maison, M., \& Nazarudin, N. (2021). Development of Mobile Learning Media on Newton's Laws Using the Appy Pie Application. Jurnal Penelitian Pendidikan IPA, 7(2), 202-206. doi: https://doi.org/10.29303/ippipa.v7i2.59

Irawati, H. and Saifuddin, M. F. (2018). Analisis Kebutuhan Pengembangan Bahan Ajar Mata Kuliah Pengantar Profesi Guru Biologi Di Pendidikan Biologi Universitas Ahmad Dahlan,
7(2), 96-99. doi: https://doi.org/10.20961/biopedagogi.v7i2.27636 [Indonesian]

I. Wijaya and R. Sefriani. 2017. Interactive Modules Based Adobe Director On Computer Assembling Subjects For Vocational Secondary School Students, VOLT J. Ilm. Pendidik. Tek. Elektro, 2(2) 73-80.

doi:http://dx.doi.org/10.30870/volt.v2i2.2116

Iwamoto, D. H., Hargis, J. \& Vuong, K. (2016). The effect of project-based learning on student performance: An action research study. International Journal for the Scholarship of Technology Enhanced Learning, 1(1), 24-42. Retrieved from: https://eric.ed.gov/?id=ED554472

Komalasari, B., Jufri, A., \& Santoso, D. (2019). Pengembangan Bahan Ajar IPA Berbasis Inkuiri Terbimbing untuk Meningkatkan Literasi Sains. Jurnal Penelitian Pendidikan IPA, 5(2), 219-227. doi:https://doi.org/10.29303/jppipa.v5i2.279 [Indonesian]

Liu, X. (2016). Motivation management of project-based learning for business English adult learners. International Journal of Higher Education, 5(3), 137145. doi: https://doi.org/10.5430/ijhe.v5n3p137

Movahedzadeh, F., Patwell, R., Rieker, J. E., \& Gonzalez, T. (2012). Project-Based Learning to Promote Effective Learning in Biotechnology Courses. Education Research International, 2012, 18. https://doi.org/10.1155/2012/536024

Mahnun, N. (2012). Media Pembelajaran (Kajian terhadap Langkah-langkah Pemilihan Media dan Implementasinya dalam Pembelajaran). $A n-$ Nida', 37(1), 27-34. doi:http://dx.doi.org/10.24014/annida.v37i1.310 [Indonesian]

Nugroho, T. U., \& Sukardi, T. (2019). Developing project based learning module of $\mathrm{CNC}$ milling mechanical technique on mechanical engineering department vocational high schools in Surakarta. IOP Conference Series: Materials Science and Engineering, 535, 12027. https://doi.org/10.1088/1757899x/535/1/012027

Nugraha, A., Subarkah, C. Z., \& Sari. (2015). Penggunaan e-module pembelajaran pada konsep sifat koligatif larutan untuk mengembangkan literasi kimia siswa. Prosiding Simposium Nasional Inovasi dan Pembelajaran Sains, 201-204. [Indonesian]

Qosyim, A., \& Priyonggo , F. V., (2017). Penerapan media pembelajaran interaktif menggunakan flash untuk materisistem gerak pada manusia. JPPIPA: Jurnal Penelitian Pendidikan IPA, 2(2). 38- 
44. Doi: http://dx.doi.org/10.26740/jppipa.v2n2 [Indonesian]

Rahmatsyah, S., \& Dwiningsih, K. (2021). Development of Interactive E-Module on The Periodic System Materials as an Online Learning Media. Jurnal Penelitian Pendidikan IPA, 7(2), 255-261. doi:https://doi.org/10.29303/jppipa.v7i2.582

Siregar, B. H., Kairuddin, Mansyur, A., \& Siregar, N. (2021). Development of Digital Book in Enhancing Students' Higher-Order Thinking Skill. Journal of Physics: Conference Series, 1819(1), $12046 . \quad$ https://doi.org/10.1088/1742$\underline{6596 / 1819 / 1 / 012046}$

Smeets, D. J. H., \& Bus, A. G. (2015). The interactive animated e-book as a word learning device for kindergartners. Applied Psycholinguistics, 36(4), 899-920.

doi:https://doi.org/10.1017/S0142716413000556

Susanti, D., Sari, L., \& Fitriani, V. (2020). Curriculum Analysis of Biological Learning Media Module Development Based on Project Based Learning (PjBL). Jurnal Penelitian Pendidikan IPA, 6(2), 157161.

doi:https://doi.org/10.29303/jppipa.v6i2.302.

Susanti, D., Fitriani, V., \& Sari, L. Y. (2020). Validity of module based on project based learning in media biology subject. Journal of Physics: Conference Series, 1521(4). https://doi.org/10.1088/17426596/1521/4/042012

Syukri, M., Yanti, D., Mahzum, E., \& Hamid, A. (2021). Development of a PjBL Model Learning Program Plan based on a STEM Approach to Improve Students' Science Process Skills. Jurnal Penelitian Pendidikan IPA, 7(2), 269-274. doi:https://doi.org/10.29303/jppipa.v7i2.680

Styla, D. \& Michalopoulou, A. (2016). Project based learning in literature: The teacher's new role and the development of student's social skills in upper secondary education. Journal of Education and Learning, 5(3), 307-314. Retrieved from: https://eric.ed.gov/?id=EJ1110466

Trianto (2013). Mendesain Model Pembelajaran Inovatif, Progresif, Konsep, Landasan, dan Implementasinya Pada Kurikulum Tingkat Satuan Pendidikan (KTSP). Jakarta: Kencana Prenada Media Group. [Indonesian]

Wekesa, N.W., \& Ongunya, R.O. (2016). Project Based Learning on Students' Performance in the Concept of Classification of Organisms Among Secondary Schools in Kenya. Journal of Education and Practice, 7, 25-31. 